\title{
EMOTIONAL INTELLIGENCE IMPACT ON EMPLOYEE PERFORMANCE - CENTRIC TO SELECT PUBLIC SECTOR HOSPITALS IN COASTAL ANDHRA PRADESH
}

\begin{tabular}{|c|c|}
\hline Mrs.D.S.V. Krishna Kumari & $\begin{array}{c}{ }^{1} \text { Research Scholar, Dept. of HRM, Acharya } \\
\text { Nagarjuna University, Guntur- 522 510, A.P. \& } \\
\text { Asst. Professor, Dept. of Business } \\
\text { Administration, KBN College, Vijayawada, A.P. }\end{array}$ \\
\hline 2 Dr. V. Tulasi Das & $\begin{array}{c}\text { Associate Professor in HRM \& Head, Dept. of } \\
\text { MBA (Hospital Administration) } \\
\text { Acharya Nagarjuna University, Guntur- } 522 \\
\text { 510, A.P. }\end{array}$ \\
\end{tabular}

\section{ABSTRACT}

Article DOI URL: https://doi.org/10.36713/epra5628

Measuring and evaluating nurses' performance are vital to identify areas for improvement in maintaining quality of service delivery and ensuring sustainability of current practices. In the present pandemic environment health care employee are working in extended shifts and worrying about safety of them as well as their family members. Because of rapid increase of corona cases, where health care employees are under heavy pressure and working in stressful environment. Government is taking initiatives but employees are still worried a lot because of different reasons. In this context understanding of their emotional status of employees is vital in ensuring employee performance. Therefore, the present article focussed on to investigate the emotional intelligence impact on employee performance.

KEYWORDS: Emotional Intelligence, Employee Performance, Service Quality, Competencies,Pandemic Environment.

\section{INTRODUCTION}

Measuring the performance of hospital nursing care is crucial to facilitate policy makers in identifying organizational needs and subsequently determine appropriate strategies and initiatives to enhance quality of care in hospitals. Effective tools in measuring nurses' performance will enable health care stakeholders to better understand and monitor the degree to which nursing care influences patient safety and health care quality (Needleman, Kurtzman, \& Kizer, 2007). Several studies have highlighted that validity of methods for measuring nurse's performance needs to be better defined (Mert \& Ekici, 2015; Rowe et. al., 2005). Failure to understand biasness in performance measurement tools can lead to erroneous conclusions about the adequacy of performance and may result to mismatch in selections of intervention/s to improve 
performance. Policy makers must assess strategy options (including single interventions and combinations) appropriate for both short- and longterm measures (i.e. over 5 years), cost to implement such strategies as well as soft/hard infrastructure requirement. Subsequently, to measure the effectiveness of such strategies, policy makers must be able to identify the correct indicators and determinant to ensure continuous improvement in deliveries of services in hospitals (Rowe et. al., 2005).

Emotional intelligence basically is the capacity to perceive and authority over our emotions and those of others, to comprehend why somebody is feeling what they are, to communicate feeling in a profitable way, to utilize the information on our and others emotions as an inspiration apparatus and a manual for building sensible connections (Wood, J.T, 2013). Building trustful relationship with the customer is the first and most significant expertise in useful consideration. These aptitudes incorporate the capacity to feel or envision another people's emotional responsiveness, comprehend and direct own emotions; recognize others' emotions, and the ability to oversee emotions of self as well as other people. These capacities knowing as emotional intelligence (EI) (Ezzatabadi et.al, 2012). At the end of the day, EI referenced as "the one's capacity to perceive individual sentiments and those of others and includes taking care of emotions phenomenally in ourselves and in our connections (Hassan H., Atwa A, 2017).

An emotional jargon is a structure square of Emotional Intelligence (EI). Examination has demonstrated that building up an emotional jargon permitting improving your correspondence with respect to feeling, which will permit you to communicate your own emotions in sound manner and better understanding the emotions of others. Lacking capability of perceiving or dealing with one's emotions cause insufficiency of getting, strife, or misery with self as well as other people. Improving abilities of EI can improve both profession and relational connections. (Sigmar et. al, 2012, Shults, A, 2015) EI is more fundamental in viable abilities than scholarly intelligence, since individuals with high EI work better inside group, set up higher cooperative aptitudes and hypothesized that for an individual to take full profit of their intellectual intelligence will needs EI first. For an individual to be emotionally savvy he ought to have the option to see one's own emotions and afterward utilize that data in meeting a far reaching medical services need of people, families and society.

\section{REVIEW OF LITERATURE}

Suhaila Haron, Aini Suzana Ariffin, Durrishah Idrus (2019), article entitled "Validating the Development of Instrument for Measuring Nurses' Performance Scale" published in Journal of Management Info, article demonstrates quantitative indices being used for content validity and reliability of Nurse Performance Questionnaire during design and development stage of the scale. These indices have evidently provided systematic criteria for items' reduction processes comprises two-step judgement process. Some limitations of content validity studies should be noted. First, experts' feedback is subjective; thus, the study is subject to bias that may exist among the experts. Secondly, quantification of content validity alone may results in collapse response category during computation of the index (Beckstead, 2009). Thus, the utilization of multiple content validity indices in this study provides multifaceted criteria for item's reduction process. Finally, limitation for NPQ may appear if content domain is not well identified.

Novia Zahrah, Azelin Aziz\& Siti Norasyikin Abdul Hamid (2019), in their article entitled "Supervisor Support and Job Performance among Nurses in Public Hospitals" published in International Journal of Management, Accounting and Economics found the results inconsistent with previous results due to that nurse perceived supervisors were not the first resource person to get help in regards to jobs. For them, perceived social support from co-workers is more needed in enhancing job performance compared to perceptions of social support from supervisors. Since, supervisors were not always round the clock in the ward for immediate assistance. Besides, the supervisor's leadership style and communication skills may not be suitable for all staff which in turn inhibits effective communication that leads to misunderstanding.

Chaojie Wang et. al., (2019), article entitled "From Artificial to Emotional Intelligence: Integrating Five Types of Intelligence to Achieve Organizational Excellence" published inInternational Journal of Management, Knowledge and Learning introduces the A2E (Artificial Intelligence to Emotional Intelligence) Integrated Intelligence Model, which blends technology and humanity to support strategic decision-making. The A2E model builds upon the Data- Information-KnowledgeWisdom (DIKW) hierarchy and Knowledge Management (KM) concepts including tacit and explicit knowledge as its theoretical foundation to integrate five different types of intelligence into a unified and coherent framework: Artificial Intelligence (AI), Business Intelligence (BI), Competitive Intelligence (CI), Decision Intelligence (DI), and Emotional Intelligence (EI).

Ranjbar Ezzatabadi $M$ et. al., (2012), article entitled 'Nurses' Emotional Intelligence Impact on the Quality of Hospital Services" published in Iran Red Cres Med J. suggested that emotional intelligence competency should be overseen through a specific relevant, authoritative or administrative circumstance (29). To recommend a few 
ramifications for human asset the board, we may infer that emotionally clever nursing staffs are bound to convey top notch benefits that pointed in numerous administrative activities in the wellbeing area as of late.

\section{OBJECTIVES}

- To study the impact of emotional intelligence dimensions on employee performance.

- To put forth suggestions based on the findings of the study.

\section{Sample and Data Collection}

A quantitative approach was followed in this exploratory study. The participants selected for this study consisted of Rangaraya Medical College, Guntur Medical College and Andhra Medical College hospital employees. 500 questionnaires were distributed among the three hospitals in the ratio of number of employees working in the hospital. Convenience sampling technique was deployed in sample selection. The respondents were solicited to complete the Employee Performance and Emotional Intelligence questionnaire. The resultant response rate of useable questionnaires was 90\% (450).

\section{DATA ANALYSIS AND INTERPRETATIONS \\ Table- 1: Regression Model of Awareness of Emotions on Employee Performance in Public Sector Hospital Employees}

\begin{tabular}{|c|c|c|c|c|}
\hline \multicolumn{5}{|c|}{ Model Summary } \\
\hline Model & $\mathbf{R}$ & R Square & $\begin{array}{l}\text { Adjusted R } \\
\text { Square }\end{array}$ & $\begin{array}{l}\text { Std. Error of } \\
\text { the Estimate }\end{array}$ \\
\hline 1 & $.772^{\mathrm{a}}$ & .596 & .592 & .72906 \\
\hline \multicolumn{5}{|c|}{$\begin{array}{l}\text { a. Predictors: (Constant), I can converse with other colleagues from } \\
\text { the team about the emotions I experience, I can clarify the emotions } \\
\text { I feel to colleagues, I can talk about the emotions I feel to other } \\
\text { colleagues, On the off chance that I am down, I can tell colleagues } \\
\text { what will cause me to feel better }\end{array}$} \\
\hline
\end{tabular}

From the above table it is observed that the correlation coefficient $\mathrm{R}=.772$. It indicates the relation between awareness of emotions of Emotional Intelligence and employee performance is constructive and both alter in the identical path. The coefficient of variation $\mathrm{R}^{2}$ shows that $59.6 \%$ of the deviation in the dependant factor (employee performance) is explained by the independent factor (awareness of emotions). The adjusted $\mathrm{R}^{2}$ mentioned in the above table shows the generalizability of the model. It enables generalising the result obtained from the public sector hospital employees to the sample universe. It is observed that the value of the adjusted $\mathrm{R}^{2}=.592$ is close to the value of $\mathrm{R}^{2}=.596$. If the adjusted $\mathrm{R}^{2}$ is expelled from the $\mathrm{R}^{2}$ the value will be $(.596-.592=.004)$. This sum of decrease means that if the sample universe participates in the research and the model has been fitted then, there will be $0.4 \%$ less difference in the outcome.

\begin{tabular}{|c|c|c|c|c|c|}
\hline \multicolumn{6}{|c|}{ ANOVA $^{b}$} \\
\hline Model & Sum of Squares & df & Mean Square & $\mathbf{F}$ & Sig. \\
\hline Regression & 349.035 & 4 & 87.259 & 164.168 & $.000^{\mathrm{a}}$ \\
\hline Residual & 236.527 & 445 & .532 & & \\
\hline Total & 585.562 & 449 & & & \\
\hline \multicolumn{6}{|c|}{$\begin{array}{l}\text { a. Predictors: (Constant), I can converse with other colleagues from the team about the } \\
\text { emotions I experience, I can clarify the emotions I feel to colleagues, I can talk about the } \\
\text { emotions I feel to other colleagues, On the off chance that I am down, I can tell colleagues } \\
\text { what will cause me to feel better }\end{array}$} \\
\hline \multicolumn{6}{|c|}{ b. Dependent Variable: EP } \\
\hline
\end{tabular}

The analysis of variance (ANOVA) allows researchers to test the null hypothesis statistically. The above table shows the outcome of the ANOVA test, where the F-ratio $=164.168$ and the Pvalue $<0.05$, this outcome indicates that there is less than $5 \%$ change that an F-ratio of this value would be occur only coincidentally. Since the P-value is lesser than the significant level $(0.05)$, the null hypothesis is rejected and the alternate hypothesis is accepted signifying that awareness of emotions of emotional intelligence significantly affects public sector hospital employee's performance. 


\begin{tabular}{|l|r|r|r|r|r|}
\hline \multirow{2}{*}{ Model } & \multicolumn{2}{|c|}{$\begin{array}{c}\text { Unstandardized } \\
\text { Coefficients }\end{array}$} & $\begin{array}{c}\text { Standardized } \\
\text { Coefficients }\end{array}$ & t & Sig. \\
\cline { 2 - 5 } & B & Std. Error & Beta & & \\
\hline (Constant) & 1.133 & .114 & .949 & .000 \\
\hline $\begin{array}{l}\text { I can clarify the emotions I feel to } \\
\text { colleagues }\end{array}$ & .194 & .059 & .300 & .001 \\
\hline $\begin{array}{l}\text { I can talk about the emotions I feel } \\
\text { to other colleagues }\end{array}$ & .258 & .060 & .310 & 4.309 & .000 \\
\hline $\begin{array}{l}\text { On the off chance that I am down, I } \\
\text { can tell colleagues what will cause } \\
\text { me to feel better }\end{array}$ & .015 & .047 & .018 & .311 & .756 \\
\hline $\begin{array}{l}\text { I can converse with other colleagues } \\
\text { from the team about the emotions I } \\
\text { experience }\end{array}$ & .244 & .047 & .299 & 5.237 & .000 \\
\hline $\begin{array}{l}\text { a. Dependent Variable: EP } \\
\text { (Source: Primary Data/ Structured Questionnaire) }\end{array}$ & & & & \\
\hline
\end{tabular}

The results in the above coefficient table revealed that the awareness of emotions of emotional intelligence significantly affects public sector hospital employee's performance.

Table- 2: Regression Model of Management of own Emotions on Employee Performance in Public Sector Hospital Employees

\begin{tabular}{|c|c|c|c|c|}
\hline \multicolumn{5}{|c|}{ Model Summary } \\
\hline Model & R & R Square & $\begin{array}{c}\text { Adjusted R } \\
\text { Square }\end{array}$ & $\begin{array}{c}\text { Std. Error of } \\
\text { the Estimate }\end{array}$ \\
\hline 1 & $.681^{\mathrm{a}}$ & .463 & .459 & .84024 \\
\hline
\end{tabular}

a. Predictors: (Constant), I give a reasonable hearing to my colleagues' thoughts, I regard the assessments of colleagues regardless of whether I think they are incorrect, At the point when I am frustrated with my colleagues, I can beat my disappointment, When settling a dispute, I attempt to see all sides of a contradiction before I arrive at a conclusion (Source: Primary Data/Structured Questionnaire)

From the above table it is observed that the correlation coefficient $\mathrm{R}=.681$. It indicates the relation between management of own emotions of Emotional Intelligence and employee performance is constructive and both alter in the identical path. The coefficient of variation $\mathrm{R}^{2}$ shows that $46.3 \%$ of the deviation in the dependant factor (employee performance) is explained by the independent factor (management of own emotions). The adjusted $\mathrm{R}^{2}$ mentioned in the above table shows the generalizability of the model. It enables generalising the result obtained from the public sector hospital employees to the sample universe. It is observed that the value of the adjusted $\mathrm{R}^{2}=.459$ is close to the value of $\mathrm{R}^{2}=.463$. If the adjusted $\mathrm{R}^{2}$ is expelled from the $\mathrm{R}^{2}$ the value will be $(.463-.459=.004)$. This sum of decrease means that if the sample universe participates in the research and the model has been fitted then, there will be $0.4 \%$ less difference in the outcome.

\begin{tabular}{|c|c|c|c|c|c|}
\hline \multicolumn{7}{|c|}{ ANOVA $^{\mathbf{b}}$} \\
\hline & $\begin{array}{c}\text { Sum of } \\
\text { Squares }\end{array}$ & df & $\begin{array}{c}\text { Mean } \\
\text { Square }\end{array}$ & F & Sig. \\
\hline Regression & 271.390 & 4 & 67.848 & 96.101 & $.000^{\text {a }}$ \\
\hline Residual & 314.172 & 445 & .706 & & \\
\hline Total & 585.562 & 449 & & & \\
\hline
\end{tabular}

a. Predictors: (Constant), I give a reasonable hearing to my colleagues' thoughts, I regard the assessments of colleagues regardless of whether I think they are incorrect, At the point when I am frustrated with my colleagues, I can beat my disappointment, When settling a dispute, I attempt to see all sides of a contradiction before I arrive at a conclusion

b. Dependent Variable: EP

(Source: Primary Data/ Structured Questionnaire) 
The analysis of variance (ANOVA) allows researchers to test the null hypothesis statistically. The above table shows the outcome of the ANOVA test, where the F-ratio $=96.101$ and the $\mathrm{P}$-value $<0.05$, this outcome indicates that there is less than $5 \%$ change that an F-ratio of this value would be occur only coincidentally. Since the P-value is lesser than the significant level $(0.05)$, the null hypothesis is rejected and the alternate hypothesis is accepted signifying that management of own emotions of emotional intelligence significantly affects public sector hospital employee's performance.

\begin{tabular}{|c|c|c|c|c|c|}
\hline \multicolumn{6}{|c|}{ Coefficients $^{\mathbf{a}}$} \\
\hline \multirow[t]{2}{*}{ Model } & \multicolumn{2}{|c|}{$\begin{array}{l}\text { Unstandardized } \\
\text { Coefficients }\end{array}$} & \multirow{2}{*}{$\begin{array}{c}\begin{array}{c}\text { Standardized } \\
\text { Coefficients }\end{array} \\
\text { Beta } \\
\end{array}$} & \multirow[t]{2}{*}{$\mathbf{t}$} & \multirow[t]{2}{*}{ Sig. } \\
\hline & B & Std. Error & & & \\
\hline (Constant) & 1.634 & .122 & & 13.383 & .000 \\
\hline $\begin{array}{l}\text { I regard the assessments of } \\
\text { colleagues regardless of } \\
\text { whether I think they are } \\
\text { incorrect }\end{array}$ & .013 & .059 & .016 & .217 & .828 \\
\hline $\begin{array}{l}\text { At the point when I am } \\
\text { frustrated with my colleagues, } \\
\text { I can beat my disappointment }\end{array}$ & .172 & .059 & .215 & 2.909 & .004 \\
\hline $\begin{array}{l}\text { When settling a dispute, I } \\
\text { attempt to see all sides of a } \\
\text { contradiction before I arrive } \\
\text { at a conclusion }\end{array}$ & .283 & .054 & .351 & 5.267 & .000 \\
\hline $\begin{array}{l}\text { I give a reasonable hearing to } \\
\text { my colleagues' thoughts }\end{array}$ & .116 & .049 & .150 & 2.376 & .018 \\
\hline a. Dependent Variable: EP & & & & & \\
\hline
\end{tabular}

The results in the above coefficient table revealed that the management of own emotions of emotional intelligence significantly affects public sector hospital employee's performance.

Table- 3: Regression Model of Awareness of Others Emotions on Employee Performance in Public Sector Hospital Employees

\begin{tabular}{|c|c|c|c|c|}
\hline \multicolumn{5}{|c|}{ Model Summary } \\
\hline Model & $\mathbf{R}$ & R Square & $\begin{array}{c}\text { Adjusted R } \\
\text { Square }\end{array}$ & $\begin{array}{l}\text { Std. Error of } \\
\text { the Estimate }\end{array}$ \\
\hline 1 & $.635^{\mathrm{a}}$ & .403 & .397 & .88649 \\
\hline \multicolumn{5}{|c|}{$\begin{array}{l}\text { a. Predictors: (Constant), I can tell when colleagues don't mean } \\
\text { what they say, I am ready to portray precisely the path others in } \\
\text { the group are feeling, I can peruse my colleague's genuine } \\
\text { emotions, regardless of whether they attempt to shroud them, At } \\
\text { the point when I converse with a colleague, I can check their actual } \\
\text { emotions from their non-verbal communication }\end{array}$} \\
\hline
\end{tabular}

From the above table it is observed that the correlation coefficient $\mathrm{R}=.635$. It indicates the relation between awareness of others emotions of Emotional Intelligence and employee performance is constructive and both alter in the identical path. The coefficient of variation $\mathrm{R}^{2}$ shows that $40.3 \%$ of the deviation in the dependant factor (employee performance) is explained by the independent factor (awareness of others emotions). The adjusted $\mathrm{R}^{2}$ mentioned in the above table shows the generalizability of the model. It enables generalising the result obtained from the public sector hospital employees to the sample universe. It is observed that the value of the adjusted $\mathrm{R}^{2}=.397$ is close to the value of $\mathrm{R}^{2}=.403$. If the adjusted $\mathrm{R}^{2}$ is expelled from the $\mathrm{R}^{2}$ the value will be $(.403-.397=.006)$. This sum of decrease means that if the sample universe participates in the research and the model has been fitted then, there will be $0.6 \%$ less difference in the outcome. 


\begin{tabular}{|c|c|c|c|c|c|}
\hline \multicolumn{7}{|c|}{ ANOVA $^{\mathbf{b}}$} \\
\hline Model & $\begin{array}{c}\text { Sum of } \\
\text { Squares }\end{array}$ & df & $\begin{array}{c}\text { Mean } \\
\text { Square }\end{array}$ & F & Sig. \\
\hline Regression & 235.852 & 4 & 58.963 & 75.030 & $.000^{\text {a }}$ \\
\hline Residual & 349.710 & 445 & .786 & & \\
\hline Total & 585.562 & 449 & & & \\
\hline $\begin{array}{l}\text { a. Predictors: (Constant), I can tell when colleagues don't mean what they say, I am ready } \\
\text { to portray precisely the path others in the group are feeling, I can peruse my colleague's } \\
\text { genuine emotions, regardless of whether they attempt to shroud them, At the point when } \\
\text { I converse with a colleague, I can check their actual emotions from their non-verbal } \\
\text { communication }\end{array}$ \\
\hline
\end{tabular}

(Source: Primary Data/ Structured Questionnaire)

The analysis of variance (ANOVA) allows researchers to test the null hypothesis statistically. The above table shows the outcome of the ANOVA test, where the F-ratio $=75.030$ and the $\mathrm{P}$-value $<0.05$, this outcome indicates that there is less than $5 \%$ change that an F-ratio of this value would be occur only coincidentally. Since the P-value is lesser than the significant level (0.05), the null hypothesis is rejected and the alternate hypothesis is accepted signifying that awareness of others emotions of emotional intelligence significantly affects public sector hospital employee's performance.

\begin{tabular}{|c|c|c|c|c|c|}
\hline \multicolumn{6}{|c|}{ Coefficients $^{a}$} \\
\hline \multirow[t]{2}{*}{ Model } & \multicolumn{2}{|c|}{$\begin{array}{c}\text { Unstandardized } \\
\text { Coefficients }\end{array}$} & \multirow{2}{*}{$\begin{array}{c}\begin{array}{c}\text { Standardized } \\
\text { Coefficients }\end{array} \\
\text { Beta } \\
\end{array}$} & \multirow[t]{2}{*}{$\mathbf{t}$} & \multirow[t]{2}{*}{ Sig. } \\
\hline & B & Std. Error & & & \\
\hline (Constant) & 1.854 & .125 & & 14.803 & .000 \\
\hline $\begin{array}{l}\text { I can peruse my colleague's } \\
\text { genuine emotions, } \\
\text { regardless of whether they } \\
\text { attempt to shroud them }\end{array}$ & .219 & .035 & .301 & 6.200 & .000 \\
\hline $\begin{array}{l}\text { I am ready to portray } \\
\text { precisely the path others in } \\
\text { the group are feeling }\end{array}$ & .159 & .050 & .219 & 3.206 & .001 \\
\hline $\begin{array}{l}\text { At the point when I } \\
\text { converse with a colleague, } \\
\text { I can check their actual } \\
\text { emotions from their non- } \\
\text { verbal communication }\end{array}$ & .266 & .038 & .350 & 7.025 & .000 \\
\hline $\begin{array}{l}\text { I can tell when colleagues } \\
\text { don't mean what they say }\end{array}$ & -.095 & .047 & -.137 & -2.013 & .045 \\
\hline
\end{tabular}

(Source: Primary Data/ Structured Questionnaire)

The results in the above coefficient table revealed that the awareness of others emotions of emotional intelligence significantly affects public sector hospital employee's performance. 
Table- 4: Regression Model of Management of Others Emotions on Employee Performance in Public Sector Hospital Employees

\begin{tabular}{|c|c|c|c|c|}
\hline \multicolumn{5}{|c|}{ Model Summary } \\
\hline $\begin{array}{l}\text { Mode } \\
\text { l }\end{array}$ & $\mathrm{R}$ & R Square & $\begin{array}{l}\text { Adjusted R } \\
\text { Square }\end{array}$ & $\begin{array}{l}\text { Std. Error of } \\
\text { the Estimate }\end{array}$ \\
\hline 1 & $.656^{\mathrm{a}}$ & .430 & .425 & .86623 \\
\hline \multicolumn{5}{|c|}{$\begin{array}{l}\text { a. Predictors: (Constant), I can give the flash to get individual } \\
\text { colleagues eager, My energy can be infectious forcolleagues of } \\
\text { my team, I can get individual colleagues to share my insight for a } \\
\text { task, I am ready to brighten colleagues up when they are feeling } \\
\text { down }\end{array}$} \\
\hline
\end{tabular}

From the above table it is observed that the correlation coefficient $\mathrm{R}=.656$. It indicates the relation between management of others emotions of Emotional Intelligence and employee performance is constructive and both alter in the identical path. The coefficient of variation $\mathrm{R}^{2}$ shows that $43.0 \%$ of the deviation in the dependant factor (employee performance) is explained by the independent factor (management of others emotions). The adjusted $\mathrm{R}^{2}$ mentioned in the above table shows the generalizability of the model. It enables generalising the result obtained from the public sector hospital employees to the sample universe. It is observed that the value of the adjusted $\mathrm{R}^{2}=.425$ is close to the value of $\mathrm{R}^{2}=.430$. If the adjusted $\mathrm{R}^{2}$ is expelled from the $\mathrm{R}^{2}$ the value will be $(.430-.425=.005)$. This sum of decrease means that if the sample universe participates in the research and the model has been fitted then, there will be $0.5 \%$ less difference in the outcome.

\begin{tabular}{|c|c|c|c|c|c|}
\hline \multicolumn{7}{|c|}{ ANOVA $^{\mathbf{b}}$} & Sig. \\
\hline & $\begin{array}{c}\text { Sum of } \\
\text { Squares }\end{array}$ & df & $\begin{array}{c}\text { Mean } \\
\text { Square }\end{array}$ & F & $.000^{\text {a }}$ \\
\hline Regression & 251.651 & 4 & 62.913 & 83.843 & \\
\hline Residual & 333.911 & 445 & .750 & & \\
\hline Total & 585.562 & 449 & & & \\
\hline $\begin{array}{l}\text { a. Predictors: (Constant), I can give the flash to get individual colleagues eager, My energy } \\
\text { can be infectious forcolleagues of my team, I can get individual colleagues to share my } \\
\text { insight for a task, I am ready to brighten colleagues up when they are feeling down }\end{array}$ \\
\hline \multicolumn{7}{l}{} \\
b. Dependent Variable: EP
\end{tabular}

(Source: Primary Data/ Structured Questionnaire)

The analysis of variance (ANOVA) allows researchers to test the null hypothesis statistically. The above table shows the outcome of the ANOVA test, where the F-ratio $=83.843$ and the $\mathrm{P}$-value $<0.05$, this outcome indicates that there is less than $5 \%$ change that an F-ratio of this value would be occur only coincidentally. Since the P-value is lesser than the significant level (0.05), the null hypothesis is rejected and the alternate hypothesis is accepted signifying that management of others emotions of emotional intelligence significantly affects public sector hospital employee's performance.

\begin{tabular}{|l|c|c|c|c|c|}
\hline \multirow{2}{*}{ Model } & \multicolumn{2}{|c|}{$\begin{array}{c}\text { Unstandardized } \\
\text { Coefficients }\end{array}$} & $\begin{array}{c}\text { Standardized } \\
\text { Coefficients }\end{array}$ & t & Sig. \\
\cline { 2 - 5 } & $\mathbf{B}$ & Std. Error & Beta & & .000 \\
\hline (Constant) & 1.746 & .125 & & 14.011 & .0077 \\
\hline $\begin{array}{l}\text { My energy can be infectious } \\
\text { forcolleagues of my team }\end{array}$ & .057 & .040 & .415 & .158 \\
\hline $\begin{array}{l}\text { I am ready to brighten } \\
\begin{array}{l}\text { colleagues up when they are } \\
\text { feeling down }\end{array}\end{array}$ & .131 & .063 & .166 & 2.075 & .039 \\
\hline $\begin{array}{l}\text { I can get individual colleagues } \\
\text { to share my insight for a task }\end{array}$ & .274 & .057 & .342 & 4.838 & .000 \\
\hline $\begin{array}{l}\text { I can give the flash to get } \\
\text { individual colleagues eager }\end{array}$ & .097 & .045 & .128 & 2.132 & .034 \\
\hline $\begin{array}{l}\text { a. Dependent Variable: EP } \\
\text { (Source: Primary Data/ Structured Questionnaire) }\end{array}$ & & & & \\
\hline
\end{tabular}


The results in the above coefficient table revealed that the management of others emotions of emotional intelligence significantly affects public sector hospital employee's performance.

Table- 5: Regression Model of Emotional Intelligence Competencies on Employee Performance in Public Sector Hospital Employees

\begin{tabular}{|c|c|c|c|c|}
\hline \multicolumn{5}{|c|}{ Model Summary } \\
\hline Model & $\mathbf{R}$ & R Square & $\begin{array}{l}\text { Adjusted R } \\
\text { Square }\end{array}$ & $\begin{array}{l}\text { Std. Error of } \\
\text { the Estimate }\end{array}$ \\
\hline 1 & $.741^{\mathrm{a}}$ & .548 & .535 & .77878 \\
\hline \multicolumn{5}{|c|}{$\begin{array}{l}\text { a. Predictors: (Constant), Compassion, Self-awareness, Empathy, Self- } \\
\text { Regulation, Dominance- the desire that drives individuals to be } \\
\text { successful leaders, Social Skills, Emotional Stability- the emotional self- } \\
\text { awareness and the ability to control your own emotions, Enthusiasm- to } \\
\text { be optimistic and inspire others, Conscientiousness- to be dependable } \\
\text { and responsible in character and self-discipline, Empathy, Motivation, } \\
\text { Self- Assurance- confidence in own judgment fosters confidence in } \\
\text { others, Care }\end{array}$} \\
\hline
\end{tabular}

From the above table it is observed that the correlation coefficient $\mathrm{R}=.741$. It indicates the relation between emotional intelligence competencies of Emotional Intelligence and employee performance is constructive and both alter in the identical path. The coefficient of variation $\mathrm{R}^{2}$ shows that $54.8 \%$ of the deviation in the dependant factor (employee performance) is explained by the independent factor (emotional intelligence competencies). The adjusted $\mathrm{R}^{2}$ mentioned in the above table shows the generalizability of the model. It enables generalising the result obtained from the public sector hospital employees to the sample universe. It is observed that the value of the adjusted $\mathrm{R}^{2}=.535$ is close to the value of $\mathrm{R}^{2}=.548$. If the adjusted $\mathrm{R}^{2}$ is expelled from the $\mathrm{R}^{2}$ the value will be $(.548-.535=.013)$. This sum of decrease means that if the sample universe participates in the research and the model has been fitted then, there will be $1.3 \%$ less difference in the outcome.

\begin{tabular}{|c|c|c|c|c|c|}
\hline \multicolumn{6}{|c|}{ ANOVA $^{b}$} \\
\hline Model & $\begin{array}{c}\text { Sum of } \\
\text { Squares }\end{array}$ & df & $\begin{array}{c}\text { Mean } \\
\text { Square }\end{array}$ & $\mathbf{F}$ & Sig. \\
\hline Regression & 321.130 & 13 & 24.702 & 40.729 & $.000^{\mathrm{a}}$ \\
\hline Residual & 264.432 & 436 & .606 & & \\
\hline Total & 585.562 & 449 & & & \\
\hline \multicolumn{6}{|c|}{$\begin{array}{l}\text { a. Predictors: (Constant), Compassion , Self-awareness, Empathy, Self-Regulation, } \\
\text { Dominance- the desire that drives individuals to be successful leaders, Social Skills, } \\
\text { Emotional Stability- the emotional self-awareness and the ability to control your own } \\
\text { emotions, Enthusiasm- to be optimistic and inspire others, Conscientiousness- to be } \\
\text { dependable and responsible in character and self-discipline, Empathy, Motivation, Self- } \\
\text { Assurance- confidence in own judgment fosters confidence in others, Care }\end{array}$} \\
\hline b. Dependent Va & & & & & \\
\hline
\end{tabular}

The analysis of variance (ANOVA) allows researchers to test the null hypothesis statistically. The above table shows the outcome of the ANOVA test, where the F-ratio $=40.729$ and the $\mathrm{P}$-value $<0.05$, this outcome indicates that there is less than $5 \%$ change that an F-ratio of this value would be occur only coincidentally. Since the P-value is lesser than the significant level $(0.05)$, the null hypothesis is rejected and the alternate hypothesis is accepted signifying that emotional intelligence competencies of emotional intelligence significantly affect public sector hospital employee's performance. 


\begin{tabular}{|c|c|c|c|c|c|}
\hline \multicolumn{6}{|c|}{ Coefficients $^{\mathbf{a}}$} \\
\hline \multirow[t]{2}{*}{ Model } & \multicolumn{2}{|c|}{$\begin{array}{l}\text { Unstandardized } \\
\text { Coefficients }\end{array}$} & \multirow{2}{*}{$\begin{array}{c}\begin{array}{c}\text { Standardized } \\
\text { Coefficients }\end{array} \\
\text { Beta }\end{array}$} & \multirow[t]{2}{*}{$\mathbf{t}$} & \multirow[t]{2}{*}{ Sig. } \\
\hline & B & Std. Error & & & \\
\hline (Constant) & 1.075 & .131 & & 8.233 & .000 \\
\hline Self-awareness & .234 & .048 & 283 & 4.926 & .000 \\
\hline Empathy & .030 & .035 & .040 & .851 & .395 \\
\hline Self-Regulation & .173 & .125 & 203 & 1.389 & .166 \\
\hline Motivation & -.036 & .104 & -.043 & -.351 & .726 \\
\hline Social Skills & .043 & .036 & .059 & 1.184 & .237 \\
\hline $\begin{array}{l}\text { Emotional Stability- the } \\
\text { emotional self-awareness and } \\
\text { the ability to control your own } \\
\text { emotions }\end{array}$ & .099 & .089 & 122 & 1.111 & .267 \\
\hline $\begin{array}{l}\text { Dominance- the desire that } \\
\text { drives individuals to be } \\
\text { successful leaders }\end{array}$ & .067 & .050 & .087 & 1.335 & .183 \\
\hline $\begin{array}{l}\text { Enthusiasm- to be optimistic } \\
\text { and inspire others }\end{array}$ & -.092 & .069 & -.115 & -1.341 & .181 \\
\hline $\begin{array}{l}\text { Conscientiousness- to be } \\
\text { dependable and responsible in } \\
\text { character and self-discipline }\end{array}$ & .051 & .064 & .063 & .794 & .428 \\
\hline $\begin{array}{l}\text { Self- Assurance- confidence in } \\
\text { own judgment fosters } \\
\text { confidence in others }\end{array}$ & .043 & .041 & .057 & 1.059 & .290 \\
\hline Training Empathy & -.031 & .086 & $\begin{array}{l}.038 \\
\end{array}$ & -.356 & .722 \\
\hline Training Care & .028 & .071 & .035 & .392 & .696 \\
\hline Training Compassion & .116 & .094 & .140 & 1.227 & .221 \\
\hline a. Dependent Variable: EP & & & & & \\
\hline
\end{tabular}

The results in the above coefficient table revealed that the emotional intelligence competencies of emotional intelligence significantly affect public sector hospital employee's performance.

\section{FINDINGS}

$>$ From the analysis it is found that awareness of emotions, management of own emotions, awareness of others emotion, management of others emotions and emotional intelligence competencies are significantly impacting employee performance in select public sector hospitals.

$>$ In the select public sector hospitals awareness of emotions factors are explaining $59.6 \%$ of deviation in employee performance. From the ANOVA table it is observed that awareness of emotions is significantly impacting employee performance. Employee performance can be explained by constant value 1.133 .

$>$ In the select public sector hospitals management of own emotions factors are explaining $46.3 \%$ of deviation in employee performance. From the ANOVA table it is observed that management of own emotions is significantly impacting employee performance. Employee performance can be explained by constant value 1.634 .

$>$ In the select public sector hospitals awareness of others emotions factors are explaining $40.3 \%$ of deviation in employee performance. From the ANOVA table it is observed that awareness of others emotions is significantly impacting employee performance. Employee performance can be explained by constant value 1.854 .

$>$ In the select public sector hospitals management of others emotions factors are explaining $43.0 \%$ of deviation in employee performance. From the ANOVA table it is observed that management of others emotions is significantly impacting employee performance. Employee performance can be explained by constant value 1.746 .

$>$ In the select public sector hospitals emotional intelligence competencies are explaining $54.8 \%$ of deviation in employee performance. From the ANOVA table it is observed that emotional intelligence competencies are significantly impacting employee performance. Employee performance can be explained by constant value 1.075 . 


\section{SUGGESTIONS}

From the analysis it is found that all the emotional intelligence constructs are significantly impacting employee performance. Therefore, hospital administration has to take initiatives to enhance the emotional intelligence among employee as a tool for improving employee performance in current pandemic situation.

\section{CONCLUSION}

The current research is conducted to examine the impact of emotional intelligence on employee performance. From the research it is found that all the emotional intelligence constructs are significantly impacting employee performance. In this pandemic environment hospital staff is working under huge pressure. In this context management has to use front line managers' emotional intelligence to motive employees and improve their performance.

\section{REFERENCES}

1. Chaojie Wang, Fred Hoffman, Alvi Lim\&Jin Kwon (2019). From Artificial to Emotional Intelligence: Integrating Five Types of Intelligence to Achieve Organizational Excellence. International Journal of Management, Knowledge and Learning, 8(2), 125144.

2. Collins, S. Emotional intelligence as a non-cognitive factor in student registered nurse anesthetists. AANA Journal, 81(6); 465-75.

3. Ezzatabadi, M. R., Bahrami, M. A., Hadizadeh, F., Arab, M.,Nasiri, S., Amir esmaili, M., and Tehrani, G. A. Nurses' emotional intelligence impact on the quality of hospital services, Iran Red Crescent Med J. 2012; 14(12): 758-763.

4. Hassan H., Atwa A. Occupational Stress, Job Satisfaction and Cervical Screening Intention of Maternity Oncology Nurses, Medical Science \& Healthcare Practice, 2017; 1(1): 48-59.
5. Mert, T., \&Ekici, D. (2015). Development of an Assessment Model for Evaluating the Performance of Nursing Services. International Journal of Hospital Research, 4(1), 9-14.

6. Needleman, J., Kurtzman, E. T., \&Kizer, K. W. (2007). Performance measurement of nursing care: State of the science and the current consensus. Medical Care Research and Review, 64(2), 10543S. https:// doi.org/ 10.1177/1077558707299260.

7. NoviaZahrah, Azelin Aziz\& Siti Norasyikin Abdul Hamid (2019). Supervisor Support and Job Performance among Nurses in Public Hospitals. International Journal of Management, Accounting and Economics, Vol. 6, No. 6, Pp: 467- 476.

8. RanjbarEzzatabadi M, Bahrami MA, Hadizadeh F, Arab M, Nasiri S, Amiresmaili M, et al. (2012). Nurses' Emotional Intelligence Impact on the Quality of Hospital Services. Iran Red Cres Med J. 2012;14(12):758-63. D OI: 10.5812/ ircmj.926.

9. Rowe, A. K., De Savigny, D., Lanata, C. F. \&Victora, C. G. (2005). How can we achieve and maintain high-quality performance of health workers in low-resource settings? Lancet, 366(9490), 1026-1035.

10. Shults, A., Learning Emotional Intelligence: Training \& Assessment, A Project Submitted in Partial Fulfillment for the Degree of Master of Arts, Communication and Leadership, Park University, 2015; pp: 2-51.

11. Sigmar, L. S., Hynes, G. E., \& Hill, K. L. Strategies for Teaching Social and Emotional Intelligence in Business Communication. Business Communication Q uarterly, 2012; 75(3), 301-317.

12. SuhailaHaron, Aini SuzanaAriffin, Durrishahldrus (2019). Validating the Development of Instrument for Measuring Nurses' Performance Scale. Journal of Management Info, Vol 6 No 1(2019); Pp: 31-38.

13. Wood, J. T. Interpersonal communication: Everyday encounters. (7th ed.) 2013; Belmont: Wadsworth. 